\title{
Microscopic Versus Endoscopic Stapes Surgery: A Systematic Review and Meta-analysis
}

\author{
JIANNIS HAJIIOANNOU ${ }^{1}$, Eleni Gkrinia ${ }^{1}$, Konstantinos Tzimkas-Dakis ${ }^{1}$, Effrosyni \\ Palla $^{1}$, Alexandros Brotis ${ }^{1}$, Christos Korais ${ }^{1}$, Athanasios Saratziotis ${ }^{1}$, Vasileios Lachanas ${ }^{1}$, \\ and Charalampos Skoulakis ${ }^{2}$ \\ ${ }^{1}$ University Hospital of Larissa \\ ${ }^{2}$ General Hospital Volos
}

March 14, 2021

\begin{abstract}
Objectives Endoscopic approaches constitute a newly introduced and promising technique in the field of stapes surgery, presenting favorable outcomes, so far. This study aims to compare endoscopic and microscopic stapes surgery based on current literature evidence, in terms of their efficacy and safety characteristics. Design We conducted a systematic literature search of three medical databases (Pubmed, Cochrane Library, and Scopus). We focused on randomized controlled studies or observational studies comparing microscopic to endoscopic stapes surgery. Data related to the efficacy and safety of each technique were extracted. Outcome data were summarized using the pooled mean differences or pooled odds ratio along with their $95 \%$ confidence intervals, according to the available data. The quality of evidence was assessed according to the GRADE recommendations. Results Thirteen studies with 705 patients were included in the meta-analysis. Success rate was evaluated by estimating air-bone gap improvement, resulting in comparable outcomes for the two techniques (mean difference: $-0.20 ; 95 \%$ CI: $-0.53,0.14)$. No statistically significant difference was detected concerning postoperative complications, except for dysgeusia that was in favor of the endoscopic approach (OR: -1.46 ; 95\% CI: $-2.45,-.047$ ). The overall quality of evidence was assessed to range from "Low" to "Very Low". Conclusion Endoscopic stapes surgery is an innovative alternative to the microscopic technique, resulting in commensurate outcomes in terms of success rate and complications. Further high-quality studies are needed, to adequately compare the two approaches, particularly in terms of operation time, learning curve, cost-effectiveness, and otology surgical skills acquisition.
\end{abstract}

\section{Hosted file}

Stapedectomy Final Draft 04-03-2021 2500.pdf available at https://authorea.com/users/391829/ articles/513585-microscopic-versus-endoscopic-stapes-surgery-a-systematic-review-andmeta-analysis

\section{Hosted file}

table I.pdf available at https://authorea.com/users/391829/articles/513585-microscopicversus-endoscopic-stapes-surgery-a-systematic-review-and-meta-analysis

\section{Hosted file}

table II.pdf available at https://authorea.com/users/391829/articles/513585-microscopicversus-endoscopic-stapes-surgery-a-systematic-review-and-meta-analysis

\section{Hosted file}


table III.pdf available at https://authorea.com/users/391829/articles/513585-microscopicversus-endoscopic-stapes-surgery-a-systematic-review-and-meta-analysis

\section{Hosted file}

table IV.pdf available at https://authorea.com/users/391829/articles/513585-microscopicversus-endoscopic-stapes-surgery-a-systematic-review-and-meta-analysis

\section{Hosted file}

table V.pdf available at https://authorea.com/users/391829/articles/513585-microscopicversus-endoscopic-stapes-surgery-a-systematic-review-and-meta-analysis

\section{Hosted file}

tableVI.pdf available at https://authorea.com/users/391829/articles/513585-microscopicversus-endoscopic-stapes-surgery-a-systematic-review-and-meta-analysis

\section{Hosted file}

Figure 1.pdf available at https://authorea.com/users/391829/articles/513585-microscopicversus-endoscopic-stapes-surgery-a-systematic-review-and-meta-analysis

\section{Hosted file}

Figure 2.pdf available at https://authorea.com/users/391829/articles/513585-microscopicversus-endoscopic-stapes-surgery-a-systematic-review-and-meta-analysis

\section{Hosted file}

Figure 3.pdf available at https://authorea.com/users/391829/articles/513585-microscopicversus-endoscopic-stapes-surgery-a-systematic-review-and-meta-analysis

\section{Hosted file}

Figure 4.pdf available at https://authorea.com/users/391829/articles/513585-microscopicversus-endoscopic-stapes-surgery-a-systematic-review-and-meta-analysis

\section{Hosted file}

Figure 5.pdf available at https://authorea.com/users/391829/articles/513585-microscopicversus-endoscopic-stapes-surgery-a-systematic-review-and-meta-analysis 